\section{Birth dates in Florence...}

SIR - Recent correspondence showing a constant asymmetry in the birth-date distribution of students entering the Porto faculty of medicine ${ }^{1}$ has led us to investigate whether a similar asymmetry would emerge in the birth-date distribution of the students entering our faculty of medicine in Florence. Similar premises apply to Italian students as to Portuguese.

our faculty.

We considered the birth dates of the 957 students who had entered the Florence faculty of medicine in the five academic years from 1988 to 1992 and who were still registered on 1 January 1994. The analysis revealed the same asymmetry, constant during the five-year period.

\begin{tabular}{lllll}
\hline \multicolumn{5}{c}{ FIRENZE FACULTY OF MEDICINE - STUDENTS IN BIRTH-DATE QUARTERS } \\
\cline { 2 - 5 } Year of entry & Jan-Mar & Apr-Jun & Jul-Sep & Oct-Dec \\
$1988-89$ & $40(46.7)$ & $63(47.0)$ & $46(48.1)$ & $36(44.2)$ \\
$1989-90$ & $37(45.4)$ & $59(46.4)$ & $35(46.7)$ & $51(43.4)$ \\
$1990-91$ & $42(48.9)$ & $61(49.5)$ & $49(51.2)$ & $44(46.4)$ \\
$1991-92$ & $49(49.4)$ & $58(50.3)$ & $47(52.3)$ & $45(46.9)$ \\
$1992-93$ & $52(48.0)$ & $55(49.5)$ & $45(50.8)$ & $42(45.7)$ \\
Total & $221(238.6)$ & $296(242.7)$ & $222(249.1)$ & $218(226.6)$ \\
\hline
\end{tabular}

Starting from the 1988-89 academic year, the numerus clausus (programmed number) was introduced in almost all Italian faculties of medicine. The main result has been that entrants to the medical faculty are recruited from among the most successful high school students, due to the scarcity of places as compared to the number of interested applicants. Last year, for instance, 547 applicants competed for the 200 places available in
Our data show a significantly higher incidence of students born during the second trimester of the year. Although our figure is not so important as that found in Portugal, it is still significant $\left(\chi^{2}\right.$ $=16.28, P<0.005$ ).

The dates of birth of our students, subdivided into trimesters, are shown in the table. The expected number of students is given in parentheses, taking into account the Italian birth data for the same five years ${ }^{2}$. These data too present certain asymmetries, though not so significant as the others. It may be noted, for example, that in the 12 years for which the Italian birth data have been taken into account (1965-78) December was always (with two exceptions, which were November) the month of the year with the lowest birth numbers.

We concur with Azevedo et al. that the hypothesis of Michael Holmes ${ }^{3}$, on the importance of the seasons in the early development of the child, is very attractive, and we believe that the fact that "the self-wiring of the brain" is dependent on external stimuli ${ }^{4}$ might give weight to this hypothesis.

We hope that someone in the Southern Hemisphere will now analyse similar data, in order to confirm (or to confute) the 'spring advantage'.

\section{Vieri Boddi}

\section{Enzo Brizzi}

\section{Antonio Conti}

\section{Gian Franco Gensini}

Faculty of Medicine,

University of Firenze,

\section{1-50134 Firenze, Italy}

1. Azevedo, I., Pinto -do-ó, P, \& Borges N. Nature 376 381 (1995).

2. Nascite e decessi - Anno 1991; ISTAT (Istituto Nazionale di Statistica) Roma, 1994; Statistiche demografiche - Anni 1986, 1987, Tomo 2;Parte prima, Nascite e decessi. ISTAT,Roma, 1988.

3. Holmes M. Nature 373, 468 (1995).

4. Stryker M.P. Nature 375, 277-278 (1995). 